\title{
Green approaches for materials, wastes, and effluents treatment
}

\author{
Achraf Ghorbal $^{1,4} \cdot$ Ali Sdiri $^{2} \cdot$ Boubaker Elleuch $^{3}$ \\ Received: 7 October 2019 / Accepted: 21 October 2019/Published online: 18 November 2019 \\ (C) Springer-Verlag GmbH Germany, part of Springer Nature 2019
}

Knowledge of natural and anthropogenic sources of environmental pollutants has emerged as a requirement that goes beyond the state borders to reach a global dimension. Thus, numerous studies have been directed toward the implementation of new technologies in various environmental cleanup programs (Agrawal et al. 2019; Awasthi et al. 2019; Hare et al. 2019; Mani et al. 2019; Mishra et al. 2019; Zainith et al. 2019). These are green approaches that may elucidate different eco-friendly methods for sustainable management and cleanup of the environment. On the other hands, effluents discharge into municipal sewers by mining, metallurgy, electroplating, electronics, textile, nuclear, and other industrial effluents have become serious threats to the receiving environment. Therefore, controlling those effluents is of outmost importance (Yang et al. 2013; Sdiri et al. 2018; Sdiri 2018). A number of technologies have been developed for the removal and recovery of various pollutants including filtration, chemical precipitation, ion exchange, adsorption, electrodeposition, and membrane systems (Kesraoui et al. 2016; Othmani et al. 2017). Within the same framework, various bio- and ecomaterials have been used for the removal of toxic pollutants from aqueous solutions by adsorption technique (Maaloul

Responsible editor: Philippe Garrigues

Achraf Ghorbal

achraf.ghorbal.issat@gmail.com

$\triangle$ Boubaker Elleuch

boubaker.eleuch@enis.rnu.tn

1 Research Laboratory LR18ES33, National Engineering School of Gabes, University of Gabes, Avenue Omar Ibn El Khattab, 6029 Gabes, Tunisia

2 Laboratory of Water, Energy and Environment, National Engineering School of Sfax, University of Sfax, P. Box 1173-3038, Sfax, Tunisia

3 Laboratoire Génie Environnement Ecotechnologie, National Engineering School of Sfax, University of Sfax, P. Box 1173-3038, Sfax, Tunisia

4 Department of Chemical Industry and Processes, Higher Institute of Applied Sciences and Technology of Gabes, University of Gabes, Avenue Omar Ibn El Khattab, Gabes, Tunisia et al. 2017, 2019). Further studies were undertaken to remove dying pollutants by the implementation of advanced costeffective and green methods (Mittal et al. 2009; Saleh and Gupta 2011; Saravanan et al. 2013, 2016; Ben Arfi et al. 2017, 2019; Sadaf et al. 2019).

Strategies and pollution management tools are of great importance for stakeholders and decision-makers. Sustainable development has become a slogan for both developed and developing countries; it is now becoming a prerequisite for the appropriations granted to the countries. If the credit will contribute to the sustainable development, it will be easily granted because the progress of a nation is conditioned by the sustainable development indices (Sdiri et al. 2016).

Special attention was given to the sustainable development as a main topic of the current integrated environment management meeting. The success of a new advanced technique applied for the treatment of water, ground, and air can be highly efficient if it considers sustainable development indices. Thus, in all the processes of water treatment take account, the aspect of the sustainable development is of significant positive impact on the environment (Muga and Mihelcic 2008).

Recycling and managing wastewaters are fundamentally important for supporting the economy of water resources and therefore contribute to the efficient management of such scarce resources.

The 3rd International Conference on Integrated Environmental Management for Sustainable Development (ICIEM 2018) has been successfully held from May 2 to 5, 2018, in Sousse, Tunisia. More than 300 participants attended this event to share new findings and discuss the potential applications of such new processes that can be turned out to viable technique for sustainable development. A good and transparent work of selection has been undertaken to choose papers to inclusion in this special issue. The intense and fruitful exchange between the present researchers clearly showed their common concern to address the problem of waste and remediation together. Few problems may be specific to a given region, but similarity in the diagnosis as well as the remediation approaches demonstrated that the scientific community is in charge of bringing solutions for sustainable environmental protection. 
This special issue of Environmental Science and Pollution Research is a collection of the best papers initially presented at the 3rd ICIEM; it offers up-todate scientific research and findings carried out all over the world to protect and preserve the environment. All of the publications retained in the journal treated mechanisms of purification and recycling wastes in order to establish a viable technique that would be of great importance for developing water treatment and environmental processes. The main idea was to share the environmental impacts and the negative effects of human activities on the environment; recent achievements of researchers acting within the region for remediation, protection, and smart management of our natural resources. If our chaotic human activities are negatively impacting the main environmental components, then it is the duty of scientists to find out the right green approaches to prevent, educate, and create real hope for the forthcoming generations.

Beyond the presented results, our meeting was a great occasion of launching new collaborative actions and new networks to better face the challenges and handle the risks for our resources and human being.

So, we are really grateful for researchers who attended this edition of ICIEM; congratulations for the authors with published papers. Overall, the selected articles provide interesting aspects related to environmental awareness, assessment, remediation, and improvement, which are constructive for the strategic green solutions for wastes and effluents treatments.

Finally, we also wish to thank the scientific committee and all the reviewers for their valuable comments. Our thanks go to the Springer team for supporting the publication of these papers. Doctor Philippe Garrigues, Editor in chief of Environmental Sciences and Pollution Research, and the editorial team are acknowledged for their endless help during the review process of this special issue.

\section{References}

Agrawal PK, Shrivastava R, Verma J (2019) Bioremediation approaches for degradation and detoxification of polycyclic aromatic hydrocarbons. In: Emerging and eco-friendly approaches for waste management. Springer Singapore, Singapore, pp 99-119

Awasthi AK, Li J, Pandey AK, Khan J (2019) An overview of the potential of bioremediation for contaminated soil from municipal solid waste site. In: Emerging and eco-friendly approaches for waste management. Springer Singapore, Singapore, pp 59-68

Ben Arfi R, Karoui S, Mougin K, Ghorbal A (2017) Adsorptive removal of cationic and anionic dyes from aqueous solution by utilizing almond shell as bioadsorbent. Euro-Mediterranean J Environ Integr 2:20-13. https://doi.org/10.1007/s41207-017-0032-y
Ben Arfi R, Karoui S, Mougin K, Ghorbal A (2019) Cetyltrimethylammonium bromide-treated Phragmites australis powder as novel polymeric adsorbent for hazardous Eriochrome Black T removal from aqueous solutions. Polym Bull 76:50775102. https://doi.org/10.1007/s00289-018-2648-8

Hare V, Chowdhary P, Kumar B et al (2019) Arsenic toxicity and its remediation strategies for fighting the environmental threat. In: Emerging and eco-friendly approaches for waste management. Springer Singapore, Singapore, pp 143-170

Kesraoui A, Moussa A, Ben AG, Seffen M (2016) Biosorption of alpacide blue from aqueous solution by lignocellulosic biomass: Luffa cylindrica fibers. Environ Sci Pollut Res 23:15832-15840. https://doi.org/10.1007/s11356-015-5262-4

Maaloul N, Oulego P, Rendueles M et al (2017) Novel biosorbents from almond shells: characterization and adsorption properties modeling for $\mathrm{Cu}$ (II) ions from aqueous solutions. J Environ Chem Eng 5: 2944-2954. https://doi.org/10.1016/j.jece.2017.05.037

Maaloul N, Oulego P, Rendueles M, Ghorbal A, Díaz M (2019) Synthesis and characterization of eco-friendly cellulose beads for copper (II) removal from aqueous solutions. Environ Sci Pollut Res:1-17. https://doi.org/10.1007/s11356-018-3812-2

Mani S, Chowdhary P, Bharagava RN (2019) Textile wastewater dyes: toxicity profile and treatment approaches. In: Emerging and ecofriendly approaches for waste management. Springer Singapore, Singapore, pp 219-244

Mishra S, Chowdhary P, Bharagava RN (2019) Conventional methods for the removal of industrial pollutants, their merits and demerits. In: Emerging and eco-friendly approaches for waste management. Springer Singapore, Singapore, pp 1-31

Mittal A, Kaur D, Malviya A, Mittal J, Gupta VK (2009) Adsorption studies on the removal of coloring agent phenol red from wastewater using waste materials as adsorbents. J Colloid Interface Sci 337: 345-354. https://doi.org/10.1016/j.jcis.2009.05.016

Muga HE, Mihelcic JR (2008) Sustainability of wastewater treatment technologies. J Environ Manag 88:437-447. https://doi.org/10. 1016/j.jenvman.2007.03.008

Othmani A, Kesraoui A, Seffen M (2017) The alternating and direct current effect on the elimination of cationic and anionic dye from aqueous solutions by electrocoagulation and coagulation flocculation. Euro-Mediterranean J Environ Integr 2:6-12. https://doi.org/ 10.1007/s41207-017-0016-y

Sadaf A, Ahmad R, Ghorbal A, Elfalleh W, Khare SK (2019) Synthesis of cost-effective magnetic nano-biocomposites mimicking peroxidase activity for remediation of dyes. Environ Sci Pollut Res:1-10. https://doi.org/10.1007/s11356-019-05270-3

Saleh TA, Gupta VK (2011) Functionalization of tungsten oxide into MWCNT and its application for sunlight-induced degradation of rhodamine B. J Colloid Interface Sci 362:337-344. https://doi.org/10.1016/j.jcis.2011.06.081

Saravanan R, Karthikeyan N, Gupta VK et al (2013) ZnO/Ag nanocomposite: an efficient catalyst for degradation studies of textile effluents under visible light. Mater Sci Eng C 33:2235-2244. https://doi.org/ 10.1016/j.msec.2013.01.046

Saravanan R, Sacari E, Gracia F et al (2016) Conducting PANI stimulated $\mathrm{ZnO}$ system for visible light photocatalytic degradation of coloured dyes. J Mol Liq 221:1029-1033. https://doi.org/10.1016/j.molliq. 2016.06.074

Sdiri A (2018) Physicochemical characterization of natural dolomite for efficient removal of lead and cadmium in aqueous systems. Environ Prog Sustain Energy 37:2034-2041. https:// doi.org/10.1002/ep.12893

Sdiri A, Elleuch B, Ben Dhia H (2016) Integrated management of the environment for sustainable development. Environ Sci Pollut Res 23:1589-1591. https://doi.org/10.1007/s11356-016-7202-3 
Sdiri A, Pinho J, Ratanatamskul C (2018) Water resource management for sustainable development. Arab J Geosci 11:124-122. https://doi. org/10.1007/s12517-018-3411-z

Yang C, Liu L, Zeng T et al (2013) Highly sensitive simultaneous detection of lead(II) and barium(II) with G-quadruplex DNA in $\alpha$ hemolysin nanopore. Anal Chem 85:7302-7307. https://doi.org/ 10.1021/ac401198d

Zainith S, Chowdhary P, Bharagava RN (2019) Recent advances in physico-chemical and biological techniques for the management of pulp and paper mill waste. In: Emerging and eco-friendly approaches for waste management. Springer Singapore, Singapore, pp 271-297

Publisher's note Springer Nature remains neutral with regard to jurisdictional claims in published maps and institutional affiliations.

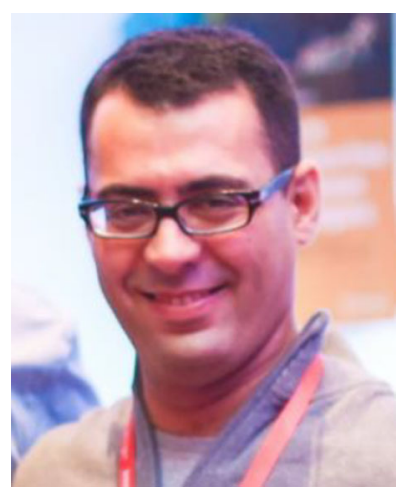

Achraf Ghorbal is the ViceDirector of the Higher Institute of Applied Sciences and Technology of Gabes, University of Gabes, Tunisia. Dr. Achraf Ghorbal obtained his M.Sc. in Processes and Materials Engineering (2003) and Ph.D. in Chemistry of Materials (2006) from the University of Haute Alsace, Mulhouse, France. Then, he joined in 2007 the French Atomic Energy Commission (Commissariat à l'énergie atomique) in Saclay, France, as a post-doctoral fellow. In 2008, he was hired as Assistant Professor and then promoted Associate Professor in Materials Sciences in 2015 at the University of Gabes, Tunisia. His research focuses on wastewater treatment, biopolymers, eco-materials, and bio-composites for environmental applications. Dr. Achraf Ghorbal authored and co-authored over 40 scientific papers (peer-reviewed papers, books, book chapters, and patents), coordinated as a principal investigator research and educational projects financed by national or international funds (e.g., Erasmus + CBHE project promoted by the European Commission Agency; Indo-Tunisian joint project), and serves as peer reviewer for several high-impact journals (e.g., Waste Management, Environmental Science and Pollution Research). His work has been internationally recognized by several prestigious distinctions such as the Springer Best Reviewer Award (2017, Euro-Mediterranean Conference for Environmental Integration). Since 2019, Dr. Achraf Ghorbal is a Managing and Developmental Editor of the Euro-Mediterranean Journal for Environmental Integration-a Springer Nature journal.

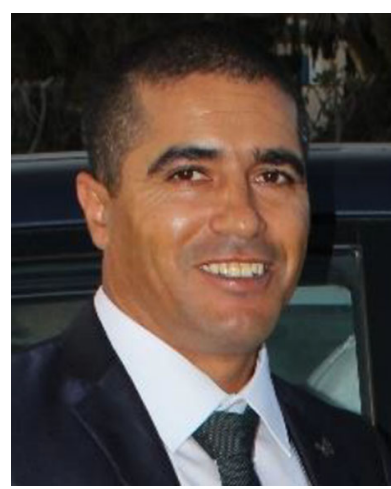

Ali Sdiri is an associate professor and a senior researcher at the National Engineering School of Sfax, Tunisia. He received his Engineering Diploma in Georesources and environments from National Engineering School of Sfax; Master in Geosciences from the Faculty of Sciences, University of Sfax, Tunisia; and $\mathrm{PhD}$ in Geoenvironmental Sciences from the Graduate School of Life and Environmental Sciences, University of Tsukuba, Japan. He joined material recycling design group at the National Institute for Materials Science (NIMS), Tsukuba, as a researcher. Since 2013, he was being hired as a staff member of the geoenvironmental department of National Engineering School of Sfax, Tunisia. His main research topic concerns the removal of hazardous metals from aqueous solutions by natural geological materials. Dr Sdiri has recently presented his habilitation in geomaterials; he published more than 50 documents in local and international peer-reviewed journals. He belongs to the editorial board of many internationally renowned journals.

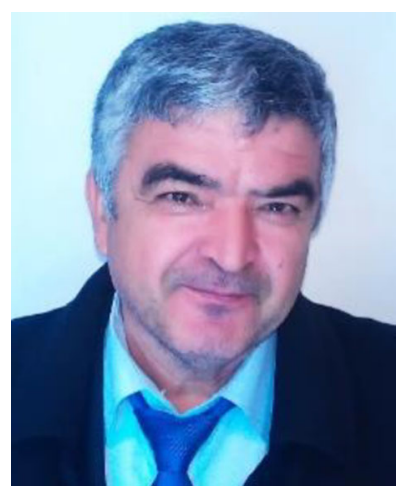

Boubaker Elleuch obtained his $\mathrm{PhD}$ at the University of Lyon, France. He published more than 60 international scientific papers and framed some 15 doctorates of young researchers. Pr Elleuch has been head of ENIS (19972003) and Head of ISET Sfax (2003-2009). Pr Elleuch organized several international scientific events and is an active funder of the research lab of Water, Energy and Environment. He is a Full professor of Organic chemistry and environment in the Engineering school of Sfax. Professor Elleuch is the director of the laboratory "Laboratoire Génie Environnement Ecotechnologie" (LGEET). 